\title{
Social Institution Versus Corruption in Indonesia
}

\author{
Syamsul Haling (Corresponding author) \\ Universitas Muhammadiyah Palu \\ J1. Jabal Nur No.1, Talise, Mantikulore, Palu City, Central Sulawesi 94118, Indonesia \\ Tel: 62-8524-0022-233Ｅ-mail: salimkito@yahoo.com
}

\begin{abstract}
Johan Jasin
Universitas Negeri Gorontalo

Jl. Jenderal Sudirman No.6, Dulalowo Timur, Gorontalo City, Gorontalo Province 96128, Indonesia
\end{abstract}

Tel: 62-8539-8625-876 E-mail: johan.jasin@ung.ac.id

Received: June 19, 2018 Accepted: July 14, 2018 Published: August 16, 2018

doi: 10.5296/jsss.v6i1.13404 URL: http://doi.org/10.5296/jsss.v6i1.13404

\begin{abstract}
Corruption has become an extraordinary crime in Indonesia and needs new approaches and strategies in its prevention and eradication. Corrupt behavior has damaged the nation's social order (individual anomalies) so that the prevention and eradication should use the institutionalized approach of social institutions in society (double legitimacy). Social institution is a religious norm because its values are embedded in the human consciousness and have become human beliefs from birth to death. In addition, everyone has a family, and if one member of the family is committing corruption, his family will get a bad image in society. Similarly, educational institutions have produced graduates who behave well so that the integration of these three social institutions corrupt behavior in Indonesia can be prevented and eradicated to restore the state financial assets.
\end{abstract}

Keywords: Corrupt behavior, Social institutions

\section{Introduction}

Corruption in Indonesia has entered into a chronic level because it has disordered the social pattern of society and parse the social pattern values and morality of the nation of Indonesia into the most corrupt nation. Corrupt behavior has the nature of corruption which is mutual 
obligations to get a mutual benefit - corruption involves an element of mutual obligations and mutual benefits (Alatas, 1997). The research results and analysis of several non-governmental organizations show the development of corrupt behavior in Indonesia. Referring to Transparency International's report in 2002 based on Berlin-Germany positioned, Indonesia was the 4th rank of the most corrupt country in the world. One year later, Indonesia's ranking increased to the sixth rank of 133 conscientious countries. Similar survey results were presented by PERC (political and Economic Risk Consultancy) to 1.000 expatriate people in a business working in 12 countries in Asia who noted that Indonesia's score reached 9.92 and this shows the fact that Indonesia has also become a hotbed of corruptors (Tanthowi, 2004).

Based on these data, it can be ascertained that since the survey results of several institutions have pointed to the fact that corrupt behavior in Indonesia is increasing, new efforts and strategies are required for Indonesia to overcome it. This paper aims to find out the factors that can combat corruption in Indonesia by raising the issue of social institutions versus corruption in Indonesia. According to Paul Horton and Chester L. Hunt, social institutions are systems of norms and relationships of unification of values and specific procedures to meet basic human needs. Such social institutions are family, religion, education, and politics as well as economics. This issue is strengthened as intellectual anxiety, and the morality of writers as the nation's children over the condition of Indonesia is getting worse due to corrupt behavior. The authors propose the issue because corrupt behavior is a fact which fundamentally opposes or contradicts to social institutions that have bound individuals, families and citizens and have institutionalized. For that reason, corrupt behavior is essential disobedience or resistance to the individual values, social, the morality of the nation which has become an established social pattern. This paper is expected to be one of the discourses in terms of finding a roadmap for Indonesia to combat corruption (McWalters, 2006). In investigating this issue, this paper used the deductive-inductive method as a way of analyzing and reconstructing the results in discussion and summarized in conclusion.

\section{Discussion}

Beginning discussion of the issues proposed as the topics of this paper, the authors offer some of the fundamental and theoretical assumptions by previous writers about corruption and theoretical assumptions about the cause of corrupt behavior. Finding out the causes of corrupt behavior is necessary due to the increasing corrupt behavior in Indonesia that it requires the effort to overcome it. Durkheiminists propose four hypothetical causes of corrupt behavior including: 1) the transformation of society becomes the cause of the decline of the morality of society which the farmers and fishermen are being an industrial community so as corrupt behavior emerges: the old values in society change, the community becomes impatient, lazy, and finally takes a shortcut (Kurkchiyan, 2000); 2) the corrupters build networks and methods through the economy to become a means of survival (Clark, 1993, Fituni, 2000, Van Duyne, 1999) as cited in Tanthowi et al. (2005); 3) the norms and values of corruption are rooted in statistically achieving bureaucracies - teaching statistical targets (Galeotti, 1998; Favatel-Garringan, 2001) communist socialist countries have embraced corrupt values and ideology (Huntington, 1998 Volkov, 2000). In general, the illustration of the emergence of corrupt behavior as a manifestation versus the values and norms of social institutions is a fact 


\section{Macrothink}

or a social phenomenon and as a marker of the process of shifting values and norms prevailing in society which is confirmed by Thomas S. Khun as cited in Rasjidi and Putra (1993). Theoretical assumption is shown in Chart 1:

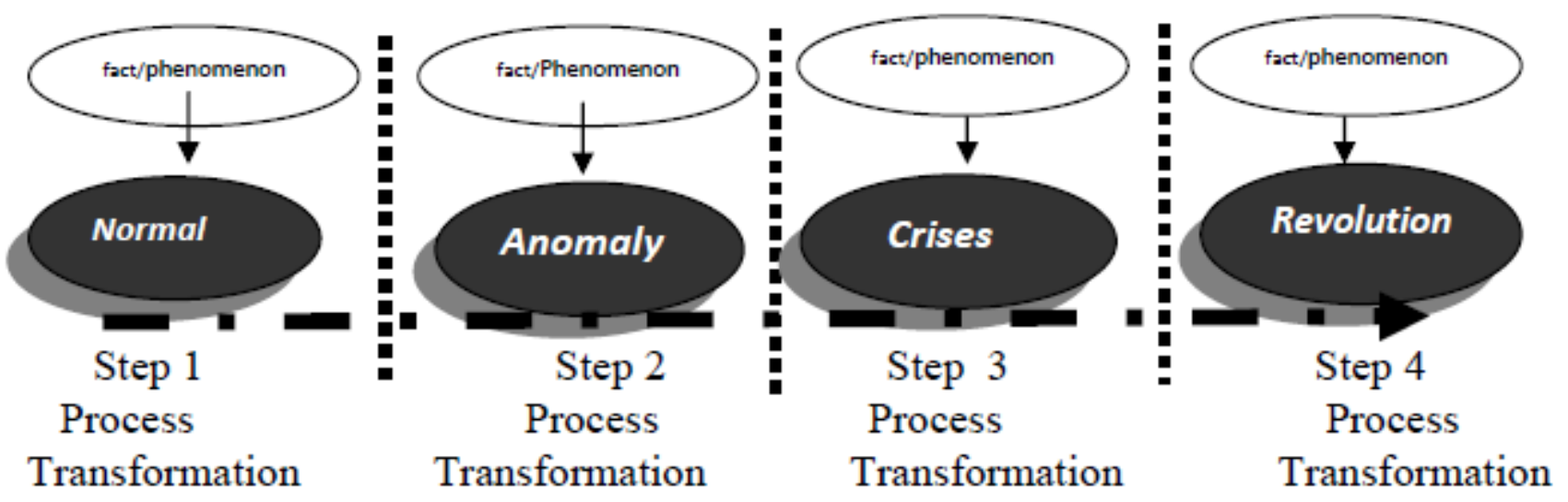

Chart 1. Transformation shifting of corrupt behavior

Based on this assumption, the efforts in overcoming corrupt behavior it can be designed by correlating it with the role of social institutions in Indonesian society as described below.

\subsection{Religious Norms}

Religious norms are one of the social institutions that bind people. Religious norm comes from a holy book that its implementation of binding is based on our belief in Almighty God. Related to corrupt behavior, religious norm principally forbids people to perform acts contrary to religious norms (corrupt behavior). Corrupt behavior is a behavior that is against (versus) religious norms, and the corruptors in Indonesia are all religious, and even they always begin an official appointment with a vow that uses the holy book. Many corrupt criminals are having belief in Almighty God. Corrupt behavior is against their own norms, meaning that corruptors are opposed to their values or they anomaly the values they embrace. In this condition, corruptors have opposed to (versus) in casu social institutions (religions) and religious norms that they believe and bind people. From several articles on the corruption countermeasure, the paper of Majelis Tarjih and Tajdid PP Muhammadiyah emphasizes on religious values as a means of preventing corruption. One of the religious values that can be used is to affirm the attitude of trust, justice, and amar ma'ruf nahi mungkar as the fundamental principle of eradicating corruption (Anwar et al, n.d.). Similarly, Rose-Ackerman (1999) in discussing corruption and cultural issues does not place social institutions as a means of combating corruption. She simply concludes that giving a gift (bribery gift) is a dynamic in a society - "but culture is dynamic and constantly changing". In the view of Majelis Tarjih and Tajdid PP Muhammadiyah, these three basic principles (trust, justice and amar ma'ruf) are repeatedly mentioned in the Qur'an showing their essence in human's life. Truth, for example, it emphasizes on honesty, straightaway, something to be maintained, performsing tasks well, (Al-Razi, Ibn Katsir, Rashid Ridha). In reality, however these social institutions do not become a control tool used by people, prospective corruptors and corruptors to fortify corrupt behavior. Norms in this social institution (trust, justice, and 
amar ma'ruf nahi mungkar) can sustain corrupt behavior including its cause. It is because the values of religious norms have been embedded naturally (built in) human consciousness and even that it does exist from birth to death. In essence, the norms of social institutions of religion should be empowered to sustain the behavior of corruptors, but to this extent, the corruptors still ignore these values and norms.

\subsection{Family}

Family is one of the social institutions in society. Soekanto (1983) Family consisting of mother, father and child as the main family member is referred to as a system of debate in the study of anthropology that means blood relations (kin) and marital relations (affinity). In that connection, each person must have a family in a functional sense of kinship. In fact, in certain areas, using the name of the relative is a family symbol and becomes an honor. The virtue of relatives in Indonesia to date is still inherently attached to every person and even into the family personality and symbols in a particular society. Therefore, the symbol of kinship (respected) is a means of preventing corruption. It is because when someone entangled in corruption, it is positively correlated to the family, meaning that a person's corrupt behavior shakes his own kinship symbol or corrupt behavior against (versus) the symbol of his family or his own kinship. Supposedly, every member of a corrupt family has a moral responsibility to keep the family symbol or an early warning so that other families are not ensnared into corruption. Thus, three members of a corrupt family from a social side have been tarnished. The emergence of criminal behavior (corrupt behavior) in the family is caused by changes in values in the family and environment (Ali, 1987) and the change causes the loss of kinship value in society. Therefore, it is necessary to strengthen those values because the kinship system and the principle of descendant that exist therein have a strong influence towards certain areas of customary law (Soekanto, 1983).

A few writing on the corruption countermeasures, this aspect is not addressed, including IAN Mc Walters writing which generally emphasizes the aspects of international cooperation, investigation authority, anti-corruption institutions, amnesty- granting to corruptors (Hong Kong); as a first step, reporting and verifying corruption, recovering asset and laundering money (McWalters, 2006). Other writings that point to the family aspect referring to community-based corruption causes are written by Fernando Castillo, Dorothy Bracey and Kwan Wing Wah (1999). They mention that the consequence of the development of civilization causes differences in society so that the society is subjected to the growing civilization, and corrupt behavior becomes difficult to avoid. Nevertheless, the influence of familial symbols (kinship values and morality) has not always been able to sustain the rate of corrupt behavior in Indonesia, although the corruptors have many kinship relationships formed, known and recognized by the people.

\subsection{Educational Institutions}

Education as a social institution can be a means of preventing corruption in Indonesia because it sustainably teaches social values through elementary school, high school, and university. As an educational institution, this institution has enormous potential to results in smart people who have noble personality and free from corrupt behavior. This is explicitly mentioned in Article 1 
Number 1 of Law Number 20 of 2003 on the National Education System: "Education is a conscious and planned effort to create an atmosphere of learning and learning process so that learners actively develop their potential to have spiritual strength, self-control, personality, intelligence, noble attitude, as well as the skills needed by them, society, nation, and country".

Based on the educational objectives, it is clear that every outcome of both formal and informal education institutions should have a personality that upholds religious values, be able to control themselves, have noble values of the nation that is undoubtedly anti-corruption. It is also an elaboration of Pancasila Education along with the country's ideology and philosophy which in principle defy corrupt behavior. Nevertheless, until now the outcome of this educational institution has not been able to be a means of eradicating corrupt behavior (preventive). This is a fact that it is difficult to dispute because all of the criminals who are subject to their criminal sanctions are the outcome of the educational institution. In fact, there are corruptors from higher education institutions, such as high schools/universities, training-education, pre-service education, etc. Some educational institutions qualified as certain officials are actually involved as the agents supporting corrupt behavior. This is revealed by Anwary (2005) who mentions several corruption cases that have been processed and sentenced in a corruption, corrupt state court. For instance, the case of SB (initial name) as the Governor of Bank Indonesia in which the country has lost 907 Billion; KH as the General Treasurer and the country has lost 6.7 Trillion (free in PN); $\mathrm{SH}$ as Aspac Bank Officials and the country has lost 408 Billion (six month appeal rate); HR as BHS officials and country has lost 3.6 trillion (lifetime in appeal rate); $\mathrm{H}$ as the Director of Bank Indonesia and the country has lost state 9.79 trillion (free appeal rate); HS as the Director of Bank Indonesia and the country has lost 6.36 Trillion (free on appeal); PS as the Director of Bank Indonesia and the country has lost 2.02 trillion (free at appeal). In addition, the article by Russell Butarbutar, referring to the research result of the Anti-Corruption Study Center of Gajah Mada University (PUKAT) concluded that all political party cadres who had been the representatives in People's Representative Council (henceforth called as DPRRI) and officials as the Ministers in United Indonesia Cabinet in 2004 - 2014 were involved in corruption cases (Butarbutar, 2015). Political party cadres who corrupted, among others are A.S. (member of DPRRI) had corrupted athletes development building and Multipurpose Building of South Sumatra; M.N. (Member of DPRRI period 2009-2014) with Bribe guesthouse Athletes Sea Games case; AM Officials of Ministry of Sports had corrupted Hambalang Project; GPN as the Governor of North Sumatera with the case of Social Assistance Bribery of North Sumatra Province; RAC as the Governor of Banten with Bribe case; the former Chairman of the Court (AM) disputes Local Goverment Election in Lebak Banten, etc.

Some of these cases have pointed to the fact that although this is not the only corrupt behavior cause until now, it is an indicator that this social institution (education) has not been able to act as the agents of corrupt behavior change in Indonesia. Therefore, it is expected that this social institution will be reinforced continuously and evaluate the process of education so that all of its outcomes will not get caught up in corrupt behavior.

\section{Conclusion}


Based on above description, this paper concludes that social institutions such as religion, family (kinship) and education cannot be a means to overcome corrupt behavior in Indonesia. Some facts indicate that social institutions have very sharp contrasts and tensions (versus) with corrupt behavior. Both conflict and tension have shaped the order of individual values and morality (individual anomalies) and have become bad behaviors both as ordinary people (bribery, gratification) and as country officials (more dominant legislative members and ministers of state, governors, and regents). There is no strong correlation among religious values and morality, family dignity (kin) and educational status held and owned by corruptors. Logical consequence is the loss of opportunity and a number of state assets intended to the development of the nation in order to achieve people's welfare. It is recommended that the existence and role of these social institutions can be reinforced synergistically in the corruption prevention in Indonesia.

\section{References}

Ackerman, S. R. (1999). Corruption and goverment: Causes, consecuency, and reform. New York: First Published in Cambridge University Press. https://doi.org/10.1017/CBO9781139175098

Adji, I. S. (2006). Korupsi, kebijakan aparatur negara dan hukum pidana [Corruption, state apparatus policy, and criminal law] (1st ed.). Jakarta: C.V. Diadit Media.

Alatas, S. H. (1997). Corruptions and the Destiny of Asia, Prentice Hall (M) Sdn. Bhd. Simon \& Schuster (Asia) Pte. Ltd, Printed in Malaysia, Bandar Sunway, Petaling Jaya, Selangor Darul Ehsan, Malaysia.

Ali, A. (1987). Menjelajahi kajian empiris terhadap hukum [Exploring empirical study towards law]. Jakarta: PT.Yasrif Watampone.

Anwar, S. (n.d.). Fikih anti korupsi persfektif muhammadiyah: Majelis tarjih dan tajdid pp muhammadiyah [Jurisprudence of anti-corruption based on Muhammadiyah perspective: majelis tarjih dan tajdid pp muhammadiyah]. Jakarta Pusat: Printing 1.

Anwary, S. (2005). Quo vadis pemberantasan korupsi di Indonesia [Quo vadis combating corruption in Indonesia]. (3rd ed.). Jakarta: AMRA, ISEPS.

Anymous. (2002). Menguak tabir hukum: Suatu kajian filosofis dan sosiologis [Revealing the law: A study on philosophy and sociology]. Cet.II. PT.Toko

Habermas, J. (2004). Krisis legitimasi [The crisis of legitimacy]. Yogyakarta: C.V. Qalam, First Printing.

Klitgard, R. (1998). Membasmi korupsi [Eradicating corruption]. (1st ed.). Jakarta.

McWalters, I. (2006). Memerangi korupsi: Sebuah peta jalan untuk Indonesia [Against corruption: A roadmap for Indonesia]. Surabaya: PT. Temprina Media Grafika, First Printing.

Posner, E. A. (2002). Law and social norms. Harvard: First Harvard University Press paperback Edition, Second Printing.

Punck, M. (1993). Coping with corruption in a borderless world. Proceedings of the Fifth International Anti-Corruption Conference, Kluwer Law and Taxation Publishers, Boston: Deventer. 


\section{Macrothink}

Journal of Social Science Studies

ISSN 2329-9150 2019, Vol. 6, No. 1

Rasjidi L., \& Putra, I. B. W. (1993). Hukum sebagai suatu sistem [Law is a system]. Bandung: PT. Remaja Rosdakarya.

Soekanto, S. (1983). Hukum adat Indonesia [Indonesian customary law]. Jakarta: PT. Raja Grafindo Persada.

Tanthowi. (2005). Membasmi kanker korupsi [Eradicating corruption cancer]. Jakarta Pusat: Religion and Civilization Study (PSAP) of Muhammadiyah, in Cooperation with Partneship, Second Printing.

Widjaya, H. A. W. (2000). Penerapan nilai-nilai pancasila dan HAM di Indonesia [The implementation of Pancasila values and human rights in Indonesia]. Jakarta: Rineka Cipta.

Yuanda., Zahra, M. (2007). 10 penguasa terkorup dunia [The world's corrupted ruler]. Yogyakarta: Pustaka Timur.

\section{Copyright Disclaimer}

Copyright for this article is retained by the author(s), with first publication rights granted to the journal.

This is an open-access article distributed under the terms and conditions of the Creative Commons Attribution license (http://creativecommons.org/licenses/by/3.0/). 